\title{
Combined impact of ultraviolet radiation and increased nutrients supply: a test of the potential anthropogenic impacts on the benthic amphipod Amphitoe valida from Patagonian waters (Argentina)
}

\author{
Macarena S. Valiñas ${ }^{1,2}$, Paula Bermejo ${ }^{1}$, Lara Galbán ${ }^{1}$, Luciana Laborda ${ }^{1}$, Donat-P. Häder $^{3 *}$, \\ Virginia E. Villafañe ${ }^{1,2}$ and E. Walter Helbling ${ }^{1,2}$ \\ 1 Estación de Fotobiología Playa Unión, Rawson, Chubut, Argentina \\ ${ }^{2}$ Consejo Nacional de Investigaciones Científicas y Técnicas, Rawson, Argentina \\ ${ }^{3}$ Department of Biology, Friedrich-Alexander Universität Erlangen Nürnberg, Möhrendorf, Germany (Retired)
}

\section{Edited by:}

Peter Rolf Richter,

Friedrich-Alexander-University,

Germany

Reviewed by:

Gaohong Wang, Chinese Academy

of Sciences, China

Aziz Ullah, Kohat University of

Science and Technology, Pakistan

*Correspondence:

Donat-P. Häder, Neue Str. 9, D-91096

Möhrendorf, Germany

e-mail:donat@dphaeder.de
Experiments were conducted during the Austral Summer of 2014 to determine the effects of increased nutrient input and ultraviolet radiation (UVR) on the food consumption rate (FCR) and food preference in the amphipod Amphitoe valida. We collected specimens from the Patagonian coast (Argentina), from beaches close (Barrancas Blancas; BB) and further away (Cangrejales; C) from the Chubut River, which constitutes the potential source of eutrophication. Organisms were exposed to different radiation regimes (full radiation vs. PAR only) and fed with different macroalgae diets (i.e., from different geographical location and with different quality in terms on nutrient content). Males collected from C showed food compensation, consuming more food under low-nutrient diets, while no compensation was observed in males from BB. Regardless of their origin, UVR decreased the FCR when males where fed on ambient nutrient diets, but not when males fed on high-quality diets indicating that in the former case, individuals were in worse physiological conditions to cope with UVR; food quality, however, significantly counteracted the deleterious effects of UVR on FCR. Females collected from the two beaches showed similar FCR under high-nutrient diet and had no food compensation when fed in low-nutrient diets. Females were more vulnerable to UVR, since their FCR were lower when exposed to UV radiation independent of the diet. Our results show that under anthropogenic eutrophication and high solar UVR levels an increase in the nutrient input could favor only males of $A$. valida, by reducing the negative effects of UVR on their FCR. Nevertheless, these nutrient inputs might cause additional problems like anoxia, as a result of an unusual macroalgal growth, thus affecting amphipod's survival.

Keywords: amphipods, global change, nutrients, Patagonia, ultraviolet radiation

\section{INTRODUCTION}

Anthropogenic activities have caused major changes on our planet through a process collectively named as climate change (IPCC, 2013), which is responsible for diverse impacts on aquatic organisms and ecosystems (Hays et al., 2005; Häder et al., 2011; Winder and Sommer, 2012). In coastal systems, these changes in climate affect the performance of individuals at various stages of their life history, influence the dispersal and recruitment at the population level and alter the abundance and the strength of interactions and trophic relationships (e.g., predator-prey) at the community level (Harley et al., 2006).

Coastal marine habitats, which play a key role from an ecological and a socio-economic point of view, seem to be very vulnerable to climate change (Cloern et al., 2014). Some of the most important effects of climate change on coastal systems include an overall decrease in the penetration of solar radiation due to increased runoff of dissolved and particulate material from terrestrial origin (Evans et al., 2006). In addition, increased amounts of nutrients, originated both from climate change (e.g., atmospheric deposition, wind, precipitation) and from increased land usage (e.g., agricultural and cattle activities) are introduced into estuaries and coastal areas (Findlay, 2005; Monteith et al., 2007). Still, organisms might be exposed to increased levels of solar ultraviolet radiation $(280-400 \mathrm{~nm})$ by at least two processes-the depletion of the ozone layer and/or the increased stratification of the water column due to global warming (Beardall et al., 2009; Häder et al., 2011).

UVR, either at normal or at increased levels cause a number of negative effects on aquatic organisms, among which some of the most documented effects are the reductions of productivity and growth rates in phytoplankton (Villafañe et al., 2003) and significant mortality, reduced fertility and changes in behavior 
in diverse zooplankton species and invertebrates (Tank et al., 2003; Przeslawski et al., 2005; Hansson and Hylander, 2009). Increased nutrient inputs are directly related to human activities, i.e., urban, industrial and agricultural effluents and urban pressure on the coast line (Figueroa and Korbee Peinado, 2010) and they occur mostly as in the form of nitrogen and phosphorus (Fong et al., 1998; Teichberg et al., 2010). The effects of such increments in nutrient availability are variable for estuarine organisms. Macroalgae, as well as benthic invertebrates, are highly affected by them and so these organisms can be used to evaluate the ecological status of coastal waters (Figueroa and Korbee Peinado, 2010).

The objective of the present study is to assess the potential impacts of UVR exposure and increase in nutrients input (i.e., via anthropogenic activity) on the amphipod Amphitoe valida (Smith, 1873) of the Chubut River estuary (Patagonia, Argentina). Because macroalgae can concentrate and bioaccumulate diverse chemical species dissolved in the water (including nutrients) carried by the river (Rabalais, 2002) we used algal specimens from two different rocky beaches, one close and one further away from the mouth of the river, to feed amphipods collected also from these two sites. We hypothesized that under a scenario of increased nutrients (e.g., from anthropogenic origin) the quality of the food consumed by amphipods will increase, and this would counteract the harmful effects of UVR on food consumption rate (FCR).

\section{METHODS}

\section{STUDY AREA AND COLLECTION OF SPECIMENS}

The Chubut River is the most important water way of the Chubut province running from the Andean Mountains and discharging into the Atlantic Ocean, forming a coastal plain mesotidal estuary (Piccolo and Perillo, 1999). The river discharge is regulated by the Florentino Ameghino Dam that is located about $120 \mathrm{~km}$ upstream from the mouth, with a mean historical river discharge of ca.
$60 \mathrm{~m}^{3} \mathrm{~s}^{-1}$ (Helbling et al., 1992). The cities of Trelew, Rawson and Gaiman (with a total of $\sim 150,000$ inhabitants) are settled on its margins. The Chubut River estuary is characterized by a wide range of physical, chemical, and biological variables due to the interaction between the river and the sea; for example, nutrients vary throughout the year within range values of $0.20-21,0.19-6.4$, and $1.7-236 \mu \mathrm{M}$ for nitrate, phosphate and silicate, respectively (Helbling et al., 2010). The river also carries particulate and dissolved materials that control the penetration of solar radiation, with attenuation coefficients of PAR $\left(\mathrm{k}_{\mathrm{PAR}}\right)$ that vary from 4 to $6 \mathrm{~m}^{-1}$ throughout the year in the inner regime (river water); in contrast, much clearer waters characterize the outer regime (seawater), with $\mathrm{k}_{\text {PAR }}$ values $<2 \mathrm{~m}^{-1}$ (Helbling et al., 2010).

Specimens of algae and amphipods were collected during the Austral summer of 2014 from two rocky beaches, in the outer regime of the Chubut River estuary (Figure 1): (1) Playa Barrancas Blancas $\left(43^{\circ} 20^{\prime} 55^{\prime \prime} \mathrm{S}, 65^{\circ} 03^{\prime} 18^{\prime \prime} \mathrm{W}\right.$, hereafter BB), closer to the mouth of the river and thus with an almost continuous exchange with river water and, (2) Playa Cangrejales $\left(43^{\circ}\right.$ $23^{\prime} \mathrm{S}, 65^{\circ} 02^{\prime} 39^{\prime \prime} \mathrm{W}$, hereafter $\mathrm{C}$ ), $4 \mathrm{~km}$ away from $\mathrm{BB}$ and thus with less exchange with river water. These beaches share some common characteristics: they are exposed to semidiurnal tides of up to $5 \mathrm{~m}$ altitude and they are dominated, in their upper and mid intertidal zone, by the Chlorophyta Ulva rigida and in the lower intertidal zone by the Rhodophyta Corallina officinalis. The most important epifaunal organisms inhabiting the intertidal, in terms of abundance are mussels (e.g., Perumytilus purpuratus), amphipods (e.g., Amphitoe valida), isopods (e.g., Idotea baltica), crabs (e.g., Cyrtograpsus angulatus and C. altimanus), limpets (e.g., Siphonaria lessoni), and barnacles (e.g., Balanus glandula) (Galbán and Valiñas, unpublished).

\section{EXPERIMENTAL PROCEDURE}

Samples of macroalgae (Ulva rigida) and amphipods (Amphitoe valida) were collected from the mid intertidal zone of both

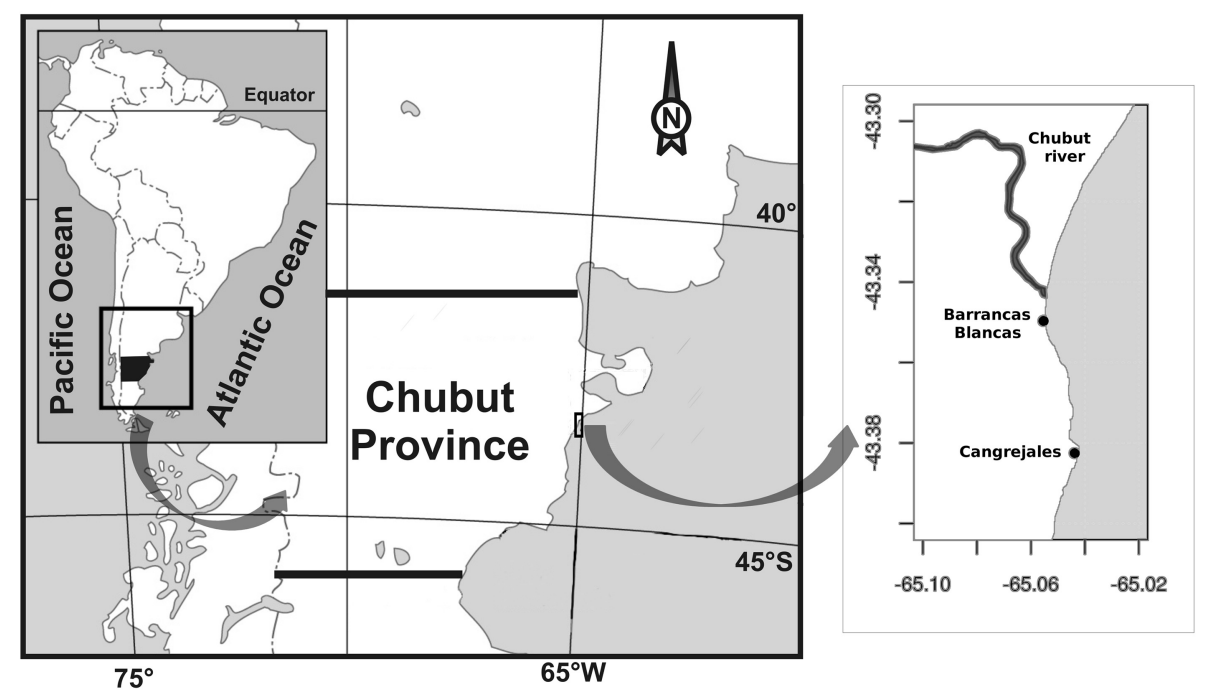

FIGURE 1 | Map showing the study area and the relative position of the beaches where amphipods and macroalgae were collected. 
beaches, $\mathrm{BB}$ and $\mathrm{C}$, stored in plastic containers and immediately taken to the laboratory at Estación de Fotobiología Playa Unión (EFPU, 20 min away from the sampling sites) where manual separation of amphipods by sex was done. Amphipods and macroalgae were maintained in containers with filtered seawater, under a $12: 12 \mathrm{~h}$ light: dark photoperiod in a temperaturecontrolled chamber $\left(20^{\circ} \mathrm{C}\right)$. After collection, $U$. rigida from $\mathrm{BB}$ and $\mathrm{C}$ were separated and half of them were kept in aquaria under ambient (in situ) nutrient conditions whereas the other half were pre-acclimated for 8 days with seawater enriched with nutrients $-80 \mu \mathrm{M}$ of $\mathrm{NaNO}_{3}, 20 \mu \mathrm{M}$ of $\mathrm{Na}_{2} \mathrm{HPO}_{4}$, and $200 \mu \mathrm{M}$ of $\mathrm{Na}_{2} \mathrm{SiO}_{3}$, i.e., in concentrations which are about 10 times higher than those previously measured in situ (i.e., $6-8 \mu \mathrm{M}$ of $\mathrm{NaNO}_{3}, 0.4-1.1 \mu \mathrm{M}$ of $\mathrm{Na}_{2} \mathrm{HPO}_{4}$, and $12-27 \mu \mathrm{M}$ of $\mathrm{Na}_{2} \mathrm{SiO}_{3}$ ). After this acclimation period, food quality increased mainly in the phosphorus content, as the ratios $\mathrm{C} / \mathrm{N} / \mathrm{P}$ changed from $17.2 / 1.78 / 1$ in the ambient nutrient concentration to $11.14 / 1.21 / 1$ in the enriched condition for macroalgae collected from BB. In the case of macroalgae collected from $\mathrm{C}$ the change was from $11.05 / 1.41 / 1$ to $11.51 / 1.18 / 1$ for ambient and enriched conditions, respectively. The water used to maintain the macroalgae was collected by boat about one mile offshore and replaced every day.

Individuals of $A$. valida were placed in 50-ml quartz tubes, fed with different diets and exposed to artificial radiation in an experimental set-up of a $2 \times 2 \times 2 \times 8$ matrix with beach (geographical location), radiation, sex, and diet as factors, respectively, as follows: (a) Beach: Individuals of A. valida collected from (1) BB or (2) C; (b) Radiation: (1) PAB treatment, specimens receiving full simulated solar radiation (PAR + UV-A + UV-B, >280 nm), uncovered tubes and (2) $\mathrm{P}$ treatment (control), specimens receiving Photosynthetic Active Radiation (PAR-> $400 \mathrm{~nm}$ ), tubes covered with Ultraphan UV Opak Digefra film; (c) Sex: (1) males and (2) females and (d) Diets: The subscript 1 and 10 indicates that the macroalgae had nutrients at in situ conditions $(\times 1)$ or enhanced concentration of nutrients by 10 times $(\times 10)$, respectively: $(1)$ $\mathrm{BB}_{1}=U$. rigida $\times 1$ from $\mathrm{BB},(2) \mathrm{C}_{1}=U$. rigida $\times 1$ from $\mathrm{C}$, (3) $\mathrm{BB}_{1} \mathrm{C}_{1}=U$. rigida $\times 1$ from $\mathrm{BB}+U$. rigida $\times 1$ from $\mathrm{C},(4)$ $\mathrm{BB}_{10}=U$. rigida $\times 10$ from $\mathrm{BB},(5) \mathrm{C}_{10}=U$. rigida $\times 10$ from $\mathrm{C}$, (6) $\mathrm{C}_{10} \mathrm{BB}_{10}=U$. rigida $\times 10$ from $\mathrm{C}+U$. rigida $\times 10$ from $\mathrm{BB}$, (7) $\mathrm{BB}_{1} \mathrm{BB}_{10}=U$. rigida $\times 1$ from $\mathrm{BB}+U$. rigida $\times 10$ from $\mathrm{BB}$, and $(8) \mathrm{C}_{1} \mathrm{C}_{10}=U$. rigida $\times 1$ from $\mathrm{C}+U$. rigida $\times 10$ from $\mathrm{C}$.

The tubes containing the amphipods were put vertically in a tray system attached to a slow stepper motor that rotated once per minute, so that the samples rotated continuously to ensure homogeneous illumination in all of them. The whole device was then put in an illuminated chamber (Sanyo MLR350), containing 10 Phillips daylight fluorescence tubes for PAR and 5 tubes Q-Panel UVA-340 for UVR, under irradiances of 164.1, 42.8, and $0.7 \mathrm{~W} \mathrm{~m}^{-2}$ of PAR, UV-A and UV-B, respectively. The total duration of the experiment was 3 days with a $12 \mathrm{~L}: 12 \mathrm{D}$ exposure periods. Experiments were performed separately, i.e., four times with males and females from each beach, due to the lack of space in the chamber. The number of replicates in each experiment was between 3 and 6 depending on the abundance of amphipod males and females found in the field, with two individuals per tube.

\section{ANALYSES AND MEASUREMENTS Feeding rates}

The diet size for amphipods consisted of rectangles $(0.5 \times 1.5 \mathrm{~cm})$ of the corresponding macroalgae diet treatment (i.e., $U$. rigida from $\mathrm{BB}, \mathrm{C}$ or a mixture of algae from the two places). In the combined diet, macroalgae were cut in both rectangles (as before) and discs $(0.9 \mathrm{~cm}$ in diameter $)$ to differentiate the food source. Each macroalga piece was carefully dried on tissue paper and its wet mass determined using a digital scale (Ohaus Pioneer ${ }^{\mathrm{TM}}$, precision: $0.1 \mathrm{mg}$ ) before being added to each tube. The food pieces were put in the tube during the morning and left until the next morning; then, the food pieces or the leftovers were taken out, rinsed, dried, and the wet weight was determined again. The same procedure was repeated during 3 consecutive days using new food each morning. There were no problems in recognizing the food from discs or rectangles after the $24 \mathrm{~h}$ feeding; however, there were slight complications with small leftover parts in some treatments. Nevertheless, the uncertainty of these measurements was $<3 \%$ of the ingested food.

The FCR was calculated as the difference between the initial and the final macroalgae wet weight and expressed as mg of macroalgae consumed permg amphipod per day. In the mixed diet treatment we calculated the FCR separately for each macroalga [i.e., in $\mathrm{BB}_{1} \mathrm{C}_{1}$, food consumption was calculated for $\mathrm{BB} 1$ (rectangles) and $\mathrm{C} 1$ (discs)] to evaluate if amphipods preferred some specific food when they had the opportunity to choose between two food options.

\section{DATA ANALYSIS}

Differences in the FCR between radiation and diets were evaluated using Two-Way ANOVA (Zar, 1999). The analyses were performed for males and females of $A$. valida collected from $\mathrm{BB}$ and C, separately. Differences in the FCR of amphipods depending on their sampling location (BB or $\mathrm{C}$ ) were evaluated for males and females separately using Three-Way ANOVA with diet, radiation, and location as factors. To evaluate if amphipods preferred some specific food in those treatments where they had the opportunity to choose between two food options, a Two-Way ANOVA was performed in males and females of $A$. valida from $\mathrm{BB}$ and $\mathrm{C}$, comparing the FCR between radiation and food option (e.g., in $\mathrm{BB}_{1} \mathrm{C}_{1}, \mathrm{C}_{10} \mathrm{BB}_{10}$, etc.).

For all statistical analyses, normality, and homoscedasticity of the data set were tested using the Kolmogorov-Smirnov and Cochran tests, respectively (Zar, 1999). When necessary, data were transformed to fit parametric assumptions. In all cases, Tukey tests were performed if the ANOVA revealed significant differences in the interactions or in the main factors.

\section{RESULTS}

Preliminary studies conducted in the area (Valiñas, unpublished) revealed significant differences in the FCR between males and females of $A$. valida. Therefore, the results of our study are presented separately, by the sex of the amphipods. In addition, those previous studies also evidenced that macroalgae from BB and $\mathrm{C}$ had similar values of nitrogen and phosphorus, but differed in their carbon content, being higher in macroalgae from BB $(8 \%$ more carbon content than in $\mathrm{C}$ ). The same analysis on amphipod 
tissue revealed that males from $\mathrm{BB}$ had $11 \%$ more carbon content that males from $\mathrm{C}$, while females from $\mathrm{C}$ had $9 \%$ more $\mathrm{C}$ than those from BB. Based on these differences, we decided to discriminate the FCR not only by sex, if also by beach on which the amphipods were collected.

\section{RESPONSES OF $\boldsymbol{A}$. VALIDA COLLECTED FROM BARRANCAS BLANCAS}

The FCR values of males of $A$. valida feeding on various diets under the different radiation treatments are shown in Figure 2. There was a significant interaction between diet and radiation on the FCR of males from BB $(P<0.05)$. Under in situ nutrient conditions UVR exerted a significant impact on FCR, causing inhibition of up to 54 and $75 \%$ for the $\mathrm{BB}_{1}$ and $\mathrm{C}_{1}$ diets, respectively, (Figures 2A,B). However, no significant differences among
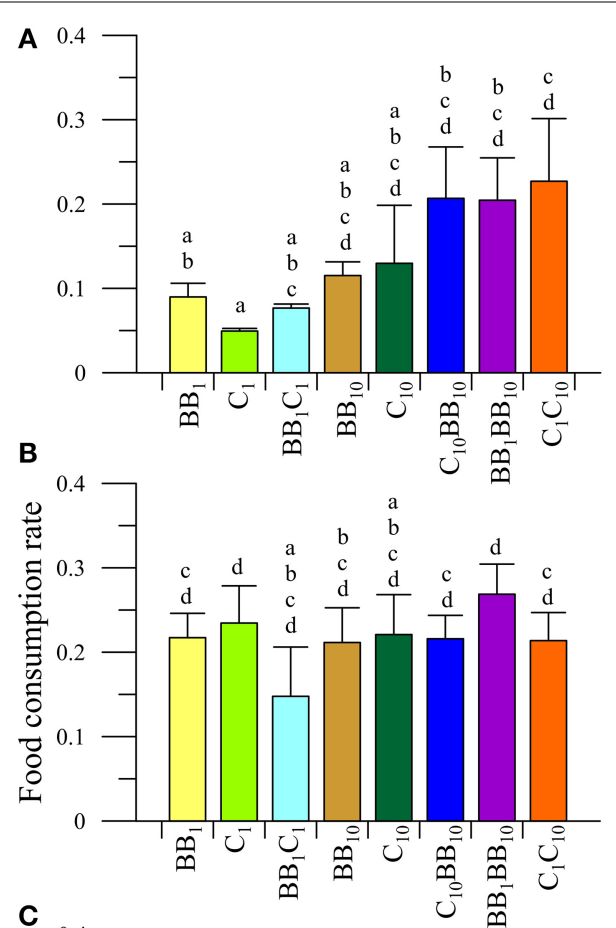

C

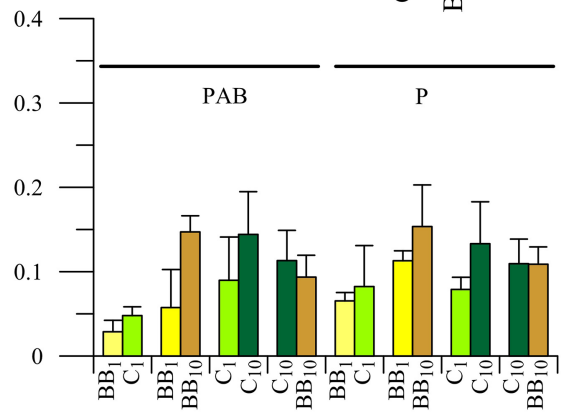

FIGURE 2 | Daily mean food consumption rates (FCR, in [mg macroalgal tissue ingested ( $\mathrm{mg}$ amphipod) $)^{-1}$ day $\left.^{-1}\right]$ ) as a function of the different diets offered to males of $A$. valida collected from Barrancas Blancas (BB) and exposed to two radiation treatments: (A) PAB and (B) P. (C) Daily mean FCR discriminated by food options in the combined diet treatments. The lines over the bars indicate the standard deviation. The result of a posteriori test for the interaction is shown with letters over the bars. radiation treatments were observed when amphipods fed on algae with high nutrient contents (i.e., $\mathrm{BB}_{10}, \mathrm{C}_{10}$, and combinations). When males had the opportunity to choose between macroalgae from $\mathrm{BB}$ or $\mathrm{C}$ at their in situ nutrient concentrations (i.e., $\mathrm{BB}_{1} \mathrm{C}_{1}$ diet, Figure $2 \mathrm{C}$ ) no interactions among diet and radiation were detected $(P>0.05)$. The analysis of the main factors showed that the FCR did not differ between diets $(P>0.05)$, but it was different between radiation treatments $(P<0.05)$. Males from $\mathrm{BB}$ consumed more food in the $\mathrm{P}$ than in the $\mathrm{PAB}$ treatment (Figure 2C). When males had the opportunity to choose between macroalgae from $\mathrm{BB}$ with different nutrient concentrations (i.e., $\mathrm{BB}_{1} \mathrm{BB}_{10}$ diet, Figure $2 \mathrm{C}$ ), no interactions were detected $(P>0.05)$. The analysis of the main factors, however, showed that the FCR differed between radiation conditions $(P<0.05)$ and diets $(P<0.05)$. Overall, males consumed more food in the $\mathrm{P}$ than in the $\mathrm{PAB}$ radiation treatment and preferred the macroalgae with the higher nutrient concentrations, so that higher FCR values were determined when feeding on $\mathrm{BB}_{10}$ than on $\mathrm{BB}_{1}$. In the $\mathrm{C}_{1} \mathrm{C}_{10}$ diet (Figure $2 \mathrm{C}$ ), no interactions between radiation and diet were observed $(P>0.05)$. Nevertheless, there were differences between diets $(P<0.05)$, with males preferring macroalgae with high concentration of nutrients (i.e., higher FCR values when feeding on $\mathrm{C}_{10}$ than when feeding on $\mathrm{C}_{1}$ ). When enriched macroalgae from $\mathrm{BB}$ and $\mathrm{C}$ were offered simultaneously (i.e., $\mathrm{C}_{10} \mathrm{BB}_{10}$ diet, Figure $2 \mathrm{C}$ ), males had similar FCR, indicating no preference for any macroalgae from a particular site.

In the case of females (Figure 3), no interactions between radiation and diets were observed in the FCR values $(P>0.05)$. There was, however, a significant impact of UVR $(P<0.05)$ with organisms consuming more food in the $\mathrm{P}$ (Figure $3 \mathrm{~B}$ ) than in the $\mathrm{PAB}$ treatment (Figure 3A). In addition, there were significant differences in the FCR values as a function of the diet $(P<0.05)$, being higher in the $\mathrm{BB}_{1} \mathrm{C}_{1}$ than in the $\mathrm{B}_{10}$ diets (Figures $\mathbf{3 A}, \mathbf{B}$ ). No other differences in the FCR between diets were detected.

Regarding food preference, neither interactions between radiation and diets, nor in the main factors (i.e., radiation and diets considered separately) were detected under the following diet conditions: $\mathrm{BB}_{1} \mathrm{C}_{1}, \mathrm{BB}_{1} \mathrm{BB}_{10}$, and $\mathrm{C}_{10} \mathrm{BB}_{10}$ (Figure $3 \mathrm{C}$ ). In the $\mathrm{C}_{1} \mathrm{C}_{10}$ diet, no interactions were detected $(P>0.05)$. The analysis of the main factors showed that the FCR did not differ between diets, without any food preference $(P>0.05)$, but it varied significantly between radiation treatments $(P<0.05)$. Females consumed more macroalgae under the $\mathrm{P}$ than under the $\mathrm{PAB}$ radiation treatments (Figure $3 \mathrm{C}$ ).

\section{RESPONSES OF A. VALIDA COLLECTED FROM CANGREJALES}

There was a significant interaction between diet and radiation $(P<0.05)$ on the FCR of males collected from C. The a posteriori analysis of the interaction (Figures $4 \mathrm{~A}, \mathrm{~B}$ ) revealed that there was a significant impact of UVR, reducing FCR when the individuals fed on algae with in situ nutrients $\left(\mathrm{BB}_{1}\right.$ and $\mathrm{C}_{1}$, Figure 4A). However, there were no differences between diets at increased nutrient levels under both radiation conditions. Males did not have any preference for macroalgae collected either from $\mathrm{BB}$ or $\mathrm{C}$ under in situ conditions (i.e., 

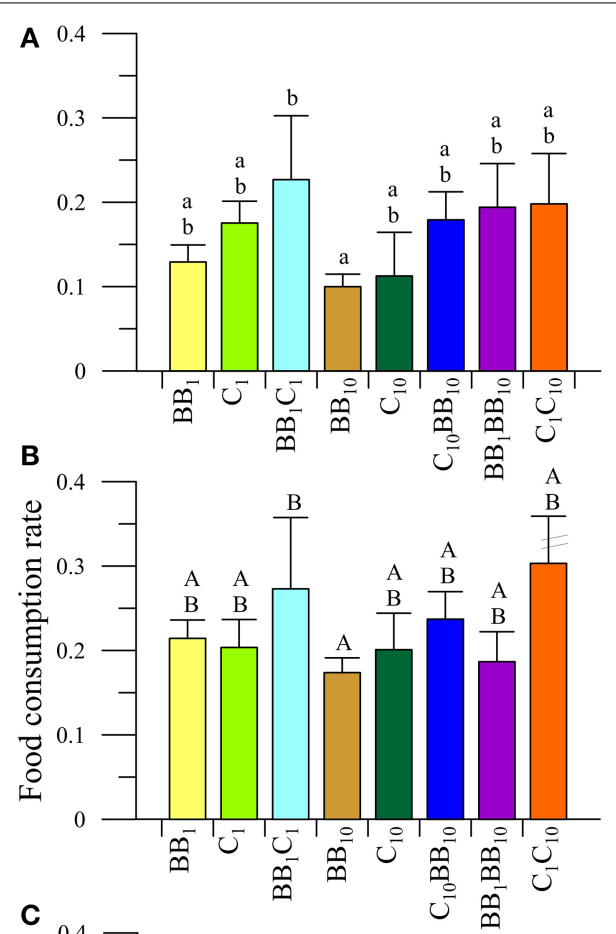

C

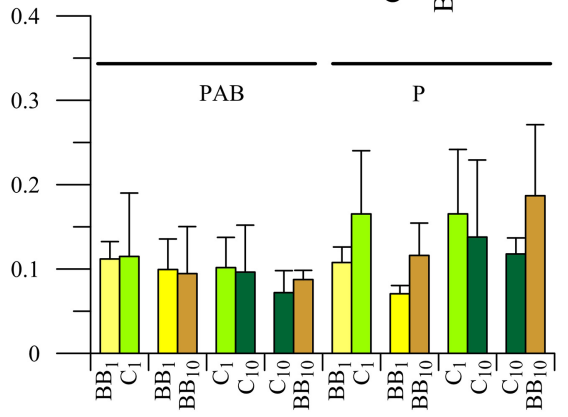

FIGURE 3 | Daily mean food consumption rates (FCR, in [mg macroalgal tissue ingested (mg amphipod) $)^{-1}$ day $\left.^{-1}\right]$ ) as a function of the different diets offered to females of $\boldsymbol{A}$. valida collected from Barrancas Blancas (BB) and exposed to two radiation treatments: $(A)$ PAB and (B) P. (C) Daily mean FCR discriminated by food options in the combined diet treatments. The lines over the bars indicate the standard deviation. Letters over the bars indicate differences between diet treatments.

$\mathrm{BB}_{1}$ or $\mathrm{C}_{1} ; P>0.05$, Figure $\left.4 \mathrm{C}\right)$, but they consumed more food under the $\mathrm{P}$ than under the $\mathrm{PAB}$ radiation treatments $(P<0.05)$.

When males had the opportunity to choose between macroalgae from $\mathrm{BB}$ with different nutrient concentrations (i.e., $\left.\mathrm{BB}_{1} \mathrm{BB}_{10}\right)$, significant differences between diets $(P<0.05)$ and radiation were observed $(P<0.05)$, consuming more food under the $\mathrm{P}$ treatment and preferring the macroalgae with high nutrient concentrations $\left(\mathrm{FCR}_{\mathrm{BB} 10}>\mathrm{FCR}_{\mathrm{BB} 1}\right)$ (Figure 4C). No food preferences were observed when males had the opportunity to choose between macroalgae from $\mathrm{C}$ with different nutrient concentrations $\left(\mathrm{C}_{1} \mathrm{C}_{10}\right.$ diet; Figure $\left.4 \mathrm{C}\right)$, neither when food from different beaches at high nutrient concentration was offered $\left(\mathrm{C}_{10} \mathrm{BB}_{10}\right.$ diet; Figure 4C).

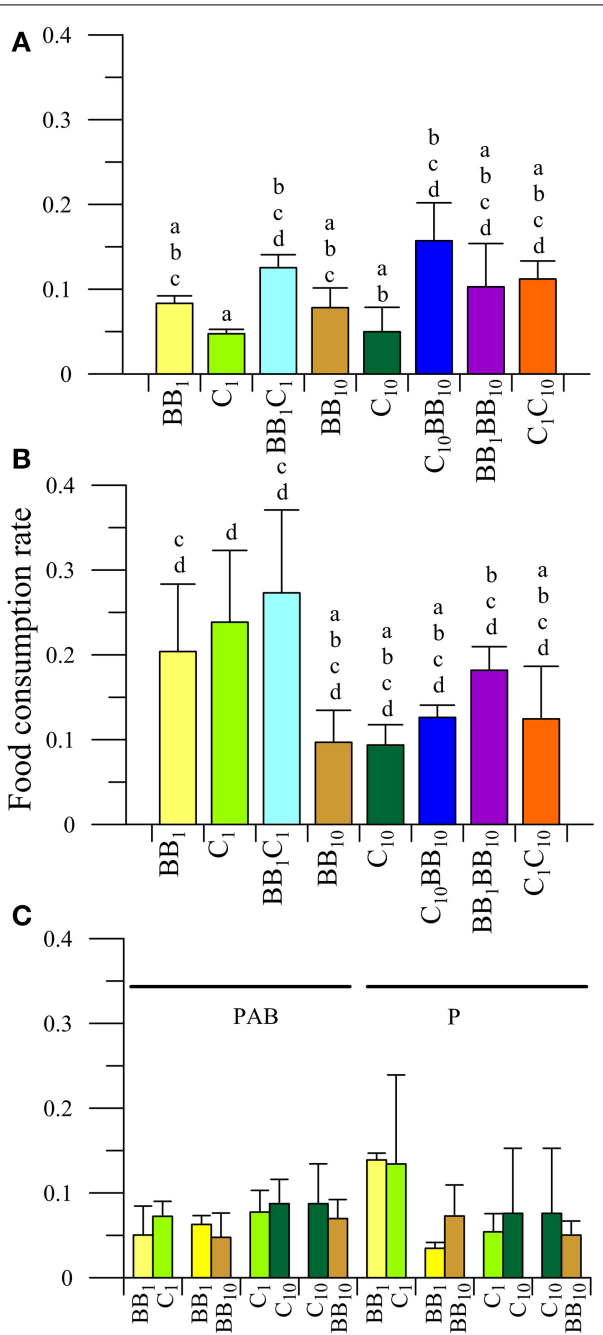

FIGURE 4 | Daily mean food consumption rates (FCR, in [mg macroalgal tissue ingested (mg amphipod) ${ }^{-1}$ day $\left.^{-1}\right]$ ) as a function of the different diets offered to males of $A$. valida collected from Cangrejales (C) and exposed to two radiation treatments: (A) PAB and (B) P. (C) Daily mean FCR discriminated by food options in the combined diet treatments. The lines over the bars indicate the standard deviation. The result of a posteriori test for the interaction is shown with letters over the bars.

There were no significant differences in the interaction between the main factors or any individual factor $(P>0.05)$ in the FCR of females of A. valida collected from $C$ (Figure 5). When macroalgae with their in situ nutrient concentration (i.e., $\mathrm{C}_{1} \mathrm{BB}_{1}$ diet) were offered to females, significant differences in food preference were observed $(P<0.05)$, preferring food from $\mathrm{C}$ rather than from BB (Figure 5C). Also differences between diets $(P<0.05)$ were observed when females had the opportunity to choose between macroalgae from $\mathrm{BB}$ with different nutrient concentrations (i.e., $\mathrm{BB}_{1} \mathrm{BB}_{10}$ diet). In this case, the preferred food was that with high nutrient concentrations: $\mathrm{FCR}_{\mathrm{BB} 10}>\mathrm{FCR}_{\mathrm{BB} 1}$ (Figure 5C). When the diets contained macroalgae from $\mathrm{C}$ but with different nutrient concentration, no differences in the FCR were detected both in the interaction $(P>0.05)$ as in the main 

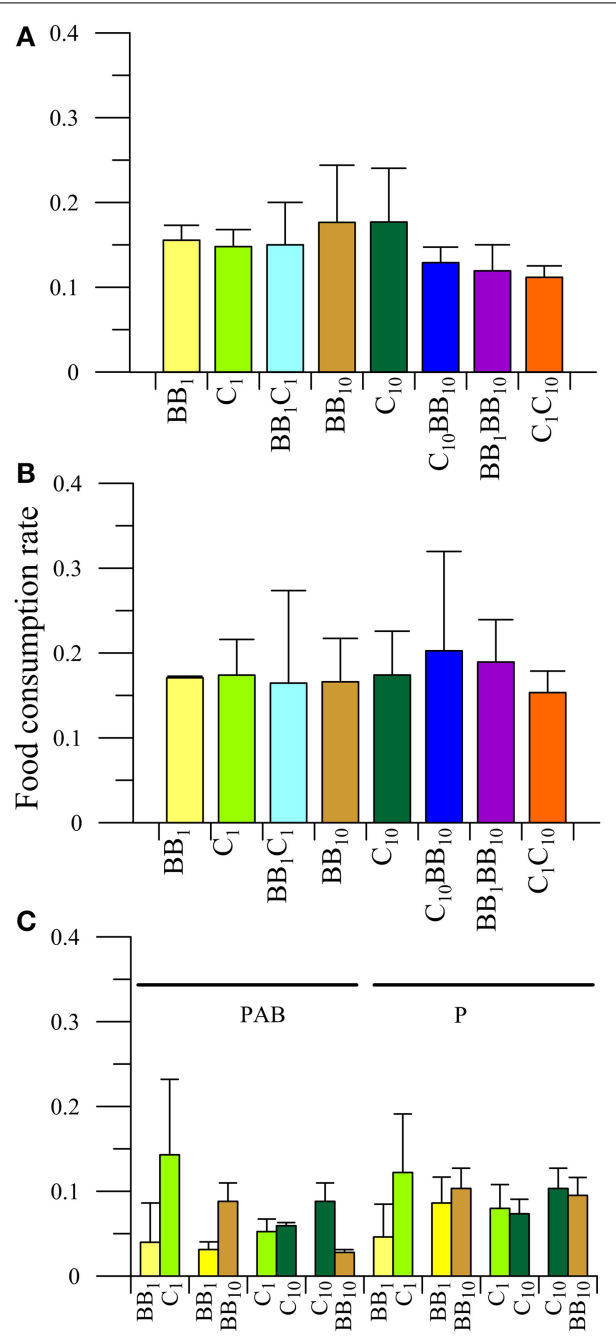

FIGURE 5 | Daily mean food consumption rates (FCR, in [mg macroalgal tissue ingested (mg amphipod) ${ }^{-1}$ day $\left.^{-1}\right]$ ) as a function of the different diets offered to females of $A$. valida collected from Cangrejales (C) and exposed to two radiation treatments: (A) PAB and (B) P. (C) Daily mean FCR discriminated by food options in the combined diet treatments. The lines over the bars indicate the standard deviation

factors (food: $P>0.05$; radiation: $P>0.05$ ), which indicated no food preferences by females and no radiation effects on the FCR (Figure 5C). When enriched macroalgae from $\mathrm{BB}$ and $\mathrm{C}$ were offered simultaneously, differences in the interaction between radiation and diets $(P<0.05)$ were observed in females. Females consumed more macroalgae from $\mathrm{C}$ in the $\mathrm{P}$ than in $\mathrm{PAB}$ treatment, but no differences were observed in the FCR of macroalgae from $\mathrm{BB}$ between radiation treatments. Also, under $\mathrm{P}$ radiation treatment, females preferred macroalgae from $\mathrm{C}$ than from $\mathrm{BB}$ (Figure 5C).

\section{DIFFERENCES ON FCR BETWEEN GEOGRAPHICAL LOCATIONS}

When the FCR was compared between food, radiation and also between males from $\mathrm{BB}$ and $\mathrm{C}$ (location factor), there were significant differences in the interaction between food and beach

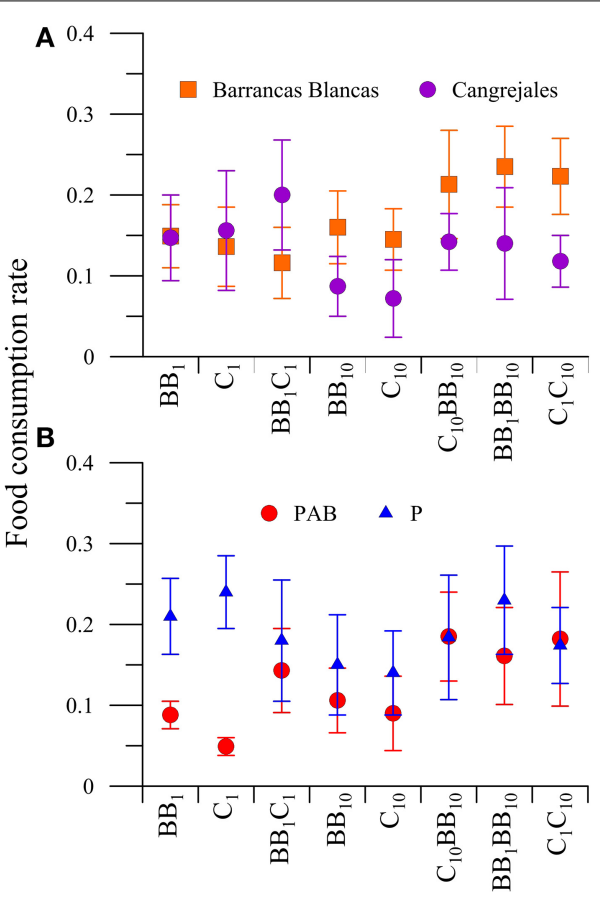

FIGURE 6 | Daily mean food consumption rates (FCR, in [mg macroalgal tissue ingested (mg amphipod) ${ }^{-1}$ day $\left.^{-1}\right]$ ) of males of $A$. valida as a function of: $(A)$ the amphipods location and diets (diet * location interaction) and (B) the diet and radiation treatment (interaction diet $*$ radiation). The lines around the symbols indicate the standard deviation.

$(P<0.05)$. Amphipod males showed a trend to consume more food from $C$ when the macroalgae offered had their natural nutrient concentration, but shifting their preference to macroalgae from $\mathrm{BB}$ when food consisted of macroalgae enriched in nutrients (single or combined diets; Figure 6A). Also, an interaction between food and radiation $(P<0.05)$ was observed in males. The a posteriori analysis of this interaction revealed that both males from $\mathrm{BB}$ and $\mathrm{C}$ consumed more food in its natural nutrient concentration when offered as only food source (i.e., $\mathrm{BB}_{1}$ or $\mathrm{C}_{1}$ ) under $\mathrm{P}$ than under $\mathrm{PAB}$ treatments (Figure 6B).

The same analysis performed with females revealed significant differences $(P<0.05)$ in the interaction between food and location (Figure 7A) and also differences between radiation treatments (Figure 7B) in the FCR. The a posteriori analysis of the interaction revealed that females from $\mathrm{BB}$ consumed more food than those from $\mathrm{C}$ in the $\mathrm{C}_{1} \mathrm{C}_{10}$ diet (Figure 7A). On the other hand, the FCR was higher in the $\mathrm{P}$ than in the PAB treatment, regardless of food, or amphipod location (Figure 7B).

\section{DISCUSSION}

Estuaries are considered important ecosystems from an ecological point of view because the exchange between the river and the sea allows for the settlement of populations adapted to a variable physico-chemical environment (Wilson, 2008). Moreover, these systems play a key role because they receive significant inputs of sediments, nutrients, and pollutants, which have important consequences for the organisms living there 


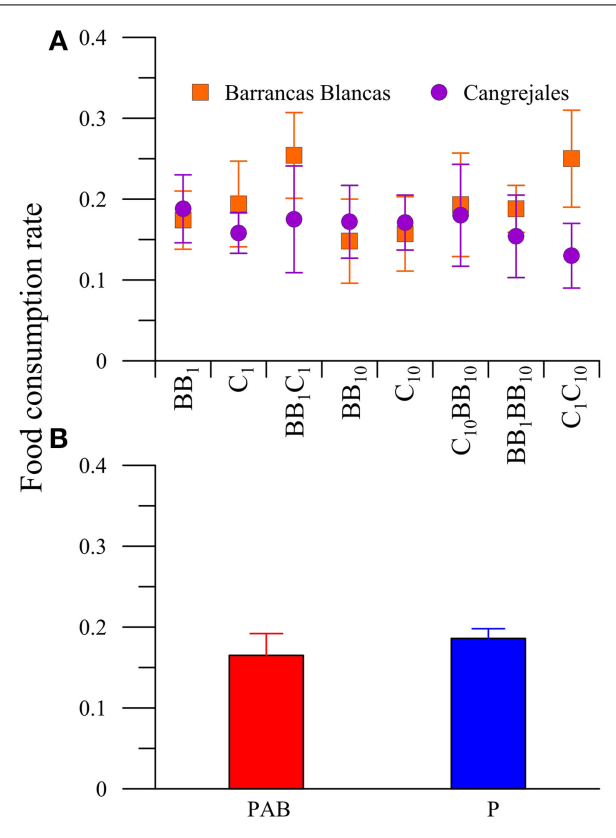

FIGURE 7 | Daily mean food consumption rates (FCR, in [mg macroalgal tissue ingested (mg amphipod) ${ }^{-1}$ day $^{-1}$ ]) of females of $A$. valida as function of: (A) the amphipods location and diets (diet * location interaction) and (B) the radiation treatment. The vertical lines indicate the standard deviation.

(Libes, 1992; Wetsteyn and Kromkamp, 1994) or in their proximity. In the case of the Chubut River, the input of nutrients is especially important due to human activities, e.g., through the use of fertilizers and input of effluents (Helbling et al., 1992). As a result, the area is characterized by a high productivity that supports an important fishery (Skewgar et al., 2007) as well as populations of birds and marine animals (Yorio and Quintana, 2008). In the last decades the Chubut River valley has increased its land use for agricultural purposes and herding, thus generating a large amount of nutrients via fertilizers that are carried out to the river. In addition, other pollutants by urban and industrial wastes are also transported into the estuary (Sastre et al., 1998; Commendatore and Esteves, 2004).

In estuaries and marine shore areas, mesoherbivores, like amphipods, constitute a high percentage of the macrofauna (Huang et al., 2006), playing an important role in the marine food web, as they are mainly responsible for the transfer of energy to higher trophic levels (Huang et al., 2006; Jacobucci and Pereira Leite, 2008). They also play an important role in controlling primary producers' biomass by grazing differentially on macrophytes, as they can select their preferred food (Ortega et al., 2010). Taking into account their importance for the upper (as food) and the lower (as macroalgal biomass control) trophic levels of the food web, any effect on the amphipod population could have serious consequences for the entire food web.

Our study indicates that there are significant interactions between the diets offered to the amphipods and the location from where the amphipods were collected (i.e., BB or C). For example, males from $\mathrm{BB}$, tended to have higher FCR when fed on diets with high nutrient content (e.g., diets containing either $\mathrm{BB}_{10}$ or $\mathrm{C}_{10}$ ) than when fed on diets with low nutrient content (e.g., $\mathrm{BB}_{1}, \mathrm{C}_{1}$ or $\mathrm{BB}_{1} \mathrm{C}_{1}$ diets). In contrast, an inverse trend was observed in males from $C$, which showed higher FCR when fed on diets with low nutrient concentration as compared to those with high nutrient concentration.

Previous studies, conducted with different macroalgae species, have shown that increased nutrient concentrations improved the quality of the food and this changed the herbivory rate (Montgomery and Gerking, 1980; Hemmi and Jormalainen, 2002; Boyer et al., 2004). It is broadly accepted that, in general, higher quality foods enhance fitness and will be selectively consumed when available (reviewed by Stephens and Krebs, 1986; CruzRivera and Hay, 2000). Thus, herbivores can optimize their diet by preferential consumption of macroalgae with a higher nutritional value (e.g., Barile et al., 2004; Ortega et al., 2010). However, some organisms can behaviorally compensate for the low quality of food by increasing their feeding rates (Rueda et al., 1991; Cruz-Rivera and Hay, 2001; Duarte et al., 2014). In doing so, herbivores may exhibit different behavioral strategies to fulfill their nutritional requirements. In our case, it is interesting to note that males from different beaches had different strategies with regard to their food consumption and optimization of the food resources. Males from $\mathrm{C}$ had higher FCR in low as compared to high nutrients, probably as a strategy to compensate the low quality of food, as it had been observed from other marine amphipods (e.g., Cruz-Rivera and Hay, 2000, 2001); but in the case of males from BB, no food compensation was observed. Compensation for low quality food has also been shown to be achieved by increasing food absorption efficiency (Simpson and Simpson, 1990), or by adjusting respiration rates (Graça et al., 1993). This latter was found in the amphipod Gammarus pulex, which could successfully compensate for low quality food by adjusting its respiration rate, rather than its ingestion rate. We cannot rule out the possibility that males from BB could have displayed some of these responses to compensate their requirements in low quality diets. The fact that males from BB tended to have higher FCR than males from $C$, when fed on diets with high nutrient content harvested from either location, could be related with differences in the physiology of organisms living in different places and adapted to different ambient conditions (i.e., different nutrient input in the intertidal area).

The changes in the FCR with different diets in the amphipod males seem to be related also to the responses of individuals to UVR, as the UVR inhibition of FCR was relatively high (49\%) when fed with ambient nutrient diets, but the inhibition decreased significantly (9\%) when males were fed on high nutrient concentration diets regardless from where the males were collected. Thus, our results lead to the conclusion that food quality significantly counteracts the deleterious effects of UVR on FCR of amphipod males. As we mentioned above, high quality food enhances fitness, as for example shown by Lastra et al. (2008) for the talitrid amphipod Megalorchestia corniculata that reached the highest growth rates when fed on high quality food. Also, CruzRivera and Hay (2000) showed that Gammarus mucronatus grew larger and produced more gonads when feeding on high quality food. In spite of this, UVR may have important effects on 
aquatic communities by altering species composition and interactions, with consequences for community structure, food web processes, and ecosystem functions such as nutrient cycling (Bothwell et al., 1994; Rozema et al., 1997). In aquatic systems, the direct deleterious effects of UVR on invertebrate abundance (Bothwell et al., 1994; Kiffney et al., 1997; Tank et al., 2003) and survivorship (McNamara and Hill, 1999) have been well documented. However, most of the studies were performed with invertebrate zooplankton species and the knowledge about UVR effects on species composition and species interactions in the marine benthos is still scarce (but see Pavia et al., 1997; Vinebrooke and Leavitt, 1999). Even though we did not perform any measurement of $A$. valida fitness, our results indicate that amphipod fed with low quality food were in worse physiological conditions to cope with UVR than those fed on high quality food and were not affected by UVR. Similar deleterious effects of UVR on A. valida were observed in a previous study, where individuals fed on green macroalgae with low amount of mycosporine-like amino acids (MAAs). These organisms showed lower survival rates than those fed on a diet rich in these photoprotective compounds (Helbling et al., 2002).

On the other hand, an interesting result was that even though males from $\mathrm{C}$ showed food compensation in low quality diets, their FCR was indeed affected by UVR, in the same way as in males from $\mathrm{BB}$; this suggests that food compensation for low quality food was not sufficient to counteract the UVR effects. As we mentioned before, the reduction of FCR by UVR when amphipods fed on ambient nutrient concentration can have direct effects on the individual fitness (i.e., growth, biomass production and reproduction). Taken into account the role that these mesoherbivores play in the trophic food web (Huang et al., 2006; Jacobucci and Pereira Leite, 2008), a detrimental effect in their fitness could have direct consequences on the entire food web. Thus, at least for FCR, eutrophication at the nutrient levels could have a positive effect on the population of males of A. valida, counteracting the effects of UVR.

Females also showed a significant interaction between the diets offered to the amphipods and the location from where the amphipods were collected, but the response was different from that for males. Females did not have such a clear distinction and had FCR values that were similar under high nutrient food, for individuals collected from either place. Only in the $B_{1} C_{1}$ diet females from $\mathrm{BB}$ tended to compensate the low food quality by increasing their FCR, but in general, it was not observed as a strategy to fulfill their nutritional requirements. As with males, possibly other mechanisms rather than compensation or consumption of high nutritional quality foods are involved in the scope of nutritional requirements. Unlike males, the effect of UVR was significant regardless of the location from where the amphipods as well as the food were collected, suggesting that the diets offered and the response to UVR were not related. Females reduced their FCR values under UVR regardless whether they fed on low or high quality food, which suggested that they are more vulnerable to radiation than males, as females could not reduce the effects of UVR when fed on high quality food. This result is of particular importance given that females are responsible for carrying the eggs and subsequently the newborns in their brood pouch and thus ensure the offspring in the population.

There is a high amount of evidence that herbivores can regulate vegetal populations by top-down control (i.e., invertebrates, Bortolus and Iribarne, 1999; fish, Burkepile and Hay, 2010). Based on our results on FCR, it seems reasonable to conclude that, in a scenario of eutrophication (as a result of anthropogenic activities) and high solar UVR levels, an increase in macroalgae food quality as a result of high nutrient inputs, could favor only males of $A$. valida, by reducing the negative effects of UVR on their FCR. Nevertheless, these nutrient inputs could lead to other problems that were not evaluated in this study. Under a high input of nutrients, macroalgae respond enhancing their growth and consequently their biomass (Pardal et al., 2000). If the level of nutrient input is highly elevated, the increment in biomass could be deleterious, producing hypoxia or anoxia as a result of oxygen depletion (Malone, 1987; Deegan, 2002; Diaz and Rosenberg, 2008), affecting the survival of organisms living on and near macroalgae (Diaz and Rosenberg, 2008), or causing migration, in the case of mobile organisms, to other parts of the intertidal (Pardal et al., 2000; Tyler and Targett, 2007). In a study performed in the eastern Atlantic Ocean (Pardal et al., 2000) it was observed that an increase in macroalgae biomass may favor A. valida populations, enhancing their growth production; however, extensive blooms, affecting the whole area of distribution of this species, had a strong negative impact and might result in their disappearance. Our work, presented here is one of the first evidences about how marine amphipods could respond to the interactive effects of UVR and increase in nutrients supply. Our original hypothesis was rejected in the case of females, while we could not reject it in the case of males. Further studies, focusing on organism fitness are needed to fully understand how these factors affected by anthropogenic activities, could modulate the population dynamics of this group that play a key role in the marine food web in intertidal environments.

\section{ACKNOWLEDGMENTS}

We thank L. Bandieri and J. Balado for their help during the experiments. We also thank the comments and suggestions of two reviewers that helped to improve our manuscript. This work was supported by Agencia Nacional de Promoción Científica y Tecnológica - ANPCyT (PICT 2011-0087 and PICT 2012-0271, Argentina), Consejo Nacional de Investigaciones Científicas y Técnicas - CONICET (PIP N 112-201001-00228, Argentina), the Cooperativa Eléctrica y de Servicios de Rawson and Fundación Playa Unión. This is Contribution 139 of the Estación de Fotobiología Playa Unión.

\section{REFERENCES}

Barile, P. J., Lapointe, B. E., and Capo, T. R. (2004). Dietary nitrogen availability in macroalgae enhances growth of the sea hare Aplysia californica (Opisthobranchia: Anaspidea). J. Exp. Mar. Biol. Ecol. 303, 65-78. doi: 10.1016/j.jembe.2003.11.004

Beardall, J., Sobrino, C., and Stojkovic, S. (2009). Interactions between the impacts of ultraviolet radiation, elevated $\mathrm{CO}_{2}$, and nutrient limitation on marine primary producers. Photochem. Photobiol. Sci. 8, 1257-1265. doi: 10.1039/b9pp00034h 
Bortolus, A., and Iribarne, O. (1999). Effects of the SW Atlantic burrowing crab Chasmagnathus granulata on a Spartina salt marsh. Mar. Ecol. Prog. Ser. 178, 79-88. doi: 10.3354/meps178079

Bothwell, M. L., Sherbot, D. M. J., and Pollock, C. M. (1994). Ecosystem response to solar ultraviolet-B radiation: influence of trophic-level interactions. Science 265, 97-100. doi: 10.1126/science.265.5168.97

Boyer, K. E., Fong, P., Armitage, A. R., and Cohen, R. A. (2004). Elevated nutrient content of tropical macroalgae increases rates of herbivory in coral, seagrass, and mangrove habitats. Coral Reefs 23, 530-538. doi: 10.1007/s00338-004-0421-y

Burkepile, D. E., and Hay, M. E. (2010). Impact of herbivore identity on algal succession and coral growth on a Caribbean reef. PLOS ONE 5:e8963. doi: 10.1371/journal.pone.0008963

Cloern, J. E., Foster, S. Q., and Fleckner, A. E. (2014). Phytoplankton primary production in the world's estuarine-coastal ecosystems. Biogeosciences 11, 2477-2501. doi: 10.5194/bg-11-2477-2014

Commendatore, M., and Esteves, J. L. (2004). Natural and anthropogenic hydrocarbons in sediments from the Chubut River (Patagonia, Argentina). Mar. Pollut. Bull. 48, 910-918. doi: 10.1016/j.marpolbul.2003.11.015

Cruz-Rivera, E., and Hay, M. E. (2000). Can quantity replace quality? Food choice, compensatory feeding, and fitness of marine mesograzers. Ecology 81, 201-219. doi: 10.1890/0012-9658(2000)081[0201:CQRQFC]2.0.CO;2

Cruz-Rivera, E., and Hay, M. E. (2001). Macroalgal traits and the feeding and fitness of an herbivorous amphipod: the roles of selectivity, mixing, and compensation. Mar. Ecol. Prog. Ser. 218, 249-266. doi: 10.3354/meps 218249

Deegan, L. A. (2002). Lessons learned: the effects of nutrient enrichment on the support of nekton by seagrass and salt marsh ecosystems. Estuaries 25, 727-742. doi: 10.1007/BF02804902

Diaz, R. J., and Rosenberg, R. (2008). Spreading dead zones and consequences for marine ecosystems. Science 321, 926-929. doi: 10.1126/science.1156401

Duarte, C., Acuña, K., Navarro, J. M., Gómez, I., Jaramillo, E., and Quijón, P. (2014). Variable feeding behavior in Orchestoidea tuberculata (Nicolet 1849): exploring the relative importance of macroalgal traits. J. Sea Res. 87, 1-7. doi: 10.1016/j.seares.2013.12.003

Evans, C. D., Chapman, P. J., Clark, J. M., Monteith, D. T., and Cresser, M. S. (2006). Alternative explanations for rising dissolved organic carbon export from organic soils. Glob. Chang. Biol. 12, 2044-2053. doi: 10.1111/j.13652486.2006.01241.x

Figueroa, F. L., and Korbee Peinado, N. (2010). "Interactive effects of UV radiation and nutrients on ecophysiology: vulnerability and adaptation to climate change," in Seaweeds and Their Role in Globally Changing Environments, eds A. Israel, R. Einav, and J. Seckbach (London; New York, NY: Springer), 157-182.

Findlay, S. E. G. (2005). Increased carbon transport in the Hudson River: unexpected consequence of nitrogen deposition? Front. Ecol. Environ. 3, 133-137. doi: 10.1890/1540-9295(2005)003[0133:ICTITH]2.0.CO;2

Fong, P., Boyer, K. E., and Zedler, J. B. (1998). Developing an indicator of nutrient enrichment in coastal estuaries and lagoons using tissue nitrogen content of the opportunistic alga, Enteromorpha intestinalis (L. Link). J. Exp. Mar. Biol. Ecol. 231, 63-79. doi: 10.1016/S0022-0981(98)00085-9

Graça, M. A. S., Maltby, L., and Calow, P. (1993). Importance of fungi in the diet of Gammarus pulex and Asellus aquaticus: II. Effects on growth, reproduction and physiology. OecoIogia 96, 304-309.

Häder, D.-P., Helbling, E. W., Williamson, C. E., and Worrest, R. C. (2011). Effects of UV radiation on aquatic ecosystems and interactions with climate change. Photochem. Photobiol. Sci. 10, 242-260. doi: 10.1039/c0pp90036b

Hansson, L.-A., and Hylander, S. (2009). Size-structured risk assessments govern Daphnia migration. Proc. R. Soc. B Biol. Sci. 276, 331-336. doi: 10.1098/rspb.2008.1088

Harley, C. D. G., Hughes, A. R., Hultgre, K. M., Miner, B. G., Sorte, C. J. B., Thornber, C. S., et al. (2006). The impacts of climate change in coastal marine systems. Ecol. Lett. 9, 228-241. doi: 10.1111/j.1461-0248.2005.00871.x

Hays, G. C., Richardson, A. J., and Robinson, C. (2005). Climate change and marine plankton. Trends Ecol. Evol. 20, 337-344. doi: 10.1016/j.tree.2005.03.004

Helbling, E. W., Menchi, C. F., and Villafañe, V. E. (2002). Bioaccumulation and role of UV-absorbing compounds in two marine crustacean species from Patagonia, Argentina. Photochem. Photobiol. Sci. 1, 820-825. doi: 10.1039/b206584c

Helbling, E. W., Pérez, D. E., Medina, C. D., Lagunas, M. G., and Villafañe, V. E. (2010). Phytoplankton distribution and photosynthesis dynamics in the Chubut River estuary (Patagonia, Argentina) throughout tidal cycles. Limnol. Oceanogr. 55, 55-65. doi: 10.4319/lo.2010.55.1.0055
Helbling, E. W., Santamarina, J. M., and Villafañe, V. E. (1992). Chubut river estuary (Argentina): estuarine variability under different conditions of river discharge. Rev. Biología Marina 27, 73-90.

Hemmi, A., and Jormalainen, V. (2002). Nutrient enhancement increases performance of a marine herbivore via quality of its food algae. Ecology 83, 1052-1064. doi: 10.1890/0012-9658(2002)083[1052:NEIPOA]2.0.CO;2

Huang, Y. M., McClintock, J. B., Amsler, C. D., Peters, K. J., and Baker, B. J. (2006). Feeding rates of common Antarctic gammarid amphipods on ecologically important sympatric macroalgae. J. Exp. Mar. Biol. Ecol. 329, 55-65. doi: 10.1016/j.jembe.2005.08.013

IPCC. (2013). Climate Change 2013. The Physical Science Basis. New York, NY: Cambridge University Press.

Jacobucci, G. B., and Pereira Leite, F. P. (2008). Effect of temporal variation and size of herbivorous amphipods on consumption levels of Sargassum filipendula (Phaeophyta, Fucales) and their main epiphyte, Hypnea musciformis. Neotrop. Biol. Conserv. 3, 78-85.

Kiffney, P. M., Little, E. E., and Clements, W. H. (1997). Influence of ultraviolet$\mathrm{B}$ radiation on the drift response of stream invertebrates. Freshw. Biol. 37, 485-492. doi: 10.1046/j.1365-2427.1997.00165.x

Lastra, M., Page, H. M., Dugan, J. E., Hubbard, D. M., and Rodil, I. F. (2008). Processing of allochthonous macrophyte subsidies by sandy beach consumers: estimates of feeding rates and impacts on food resources. Mar. Biol. 154, 163-174. doi: 10.1007/s00227-008-0913-3

Libes, S. M. (1992). An Introduction to Marine Biogeochemistry. New York, NY: John Wiley \& Sons.

Malone, T. C. (1987). "Seasonal oxygen depletion and phytoplankton production in Chesapeake Bay: preliminary results of 1985-86 field studies," in Dissolved Oxygen in the Chesapeake Bay: Processes and Effects, ed G. B. Mackiernan (Maryland: Maryland Sea Grant), 54-60.

McNamara, A. E., and Hill, W. R. (1999). Effects of UV-B dose and irradiance: comparison among grazers. J. N. Am. Benthol. Soc. 18, 370-380. doi: $10.2307 / 1468450$

Monteith, D. T., Stoddard, J. L., Evans, C. D., De Wit, H. A., Forsius, M., Høgåsen, T., et al. (2007). Dissolved organic carbon trends resulting from changes in atmospheric deposition chemistry. Nature 450, 537-541. doi: 10.1038 /nature06316

Montgomery, W. L., and Gerking, S. D. (1980). Marine macroalgae as foods for fishes: an evaluation of potential food quality. Environ. Biol. Fishes 5, 143-153. doi: 10.1007/BF02391621

Ortega, I., Diaz, Y. J., and Martín, A. (2010). Feeding rates and food preferences of the amphipods present on macroalgae Ulva sp. and Padina sp. Zool. Baetica 21, 45-53.

Pardal, M. Â., Marques, J. C., Metelo, I., Lillebo, A. I., and Flindt, M. R. (2000). Impact of eutrophication on the life cycle, population dynamics and production of Ampithoe valida (Amphipoda) along an estuarine spatial gradient (Mondego estuary, Portugal). Mar. Ecol. Prog. Ser. 196, 207-219. doi: 10.3354/meps 196207

Pavia, H., Cervin, G., Lindgren, A., and Aberg, P. (1997). Effects of UV-B radiation and simulated herbivory on phlorotannins in the brown alga Ascophyllum nodosum. Mar. Ecol. Prog. Ser. 157, 139-146. doi: 10.3354/meps157139

Piccolo, M. C., and Perillo, G. M. E. (1999). "Estuaries of Argentina: a review," in Estuaries of South America: Their Geomorphology and Dynamics, eds G. M. E. Perillo, M. C. Piccolo, and M. Pino Quivira (Berlin: Springer-Verlag), 101-132.

Przeslawski, R., Davis, A. R., and Benkendorff, K. (2005). Synergistic effects associated with climate change and the development of rocky shore molluscs. Glob. Chang. Biol. 11, 515-522. doi: 10.1111/j.1365-2486.2005.00918.x

Rabalais, N. N. (2002). Nitrogen in aquatic ecosystems. Ambio 31, 102-112. doi: 10.1579/0044-7447-31.2.102

Rozema, J., Van De Staaij, J., Björn, L. O., and Caldwell, M. (1997). UV-B as an environmental factor in plant life: stress and regulation. Trends Ecol. Evol. 12, 22-28.

Rueda, A. A., Slansky, J. F., and Wheeler, G. S. (1991). Compensatory response of the slug Sarasinula plebeia to dietary dilution. Oecologia 88, 181-188.

Sastre, A. V., Santinelli, N. H., Otaño, S. H., and Ivanissevich, M. E. (1998). Water quality in the lower section of the Chubut River, Patagonia, Argentina. Int. Ver. Theor. Angew. Limnol. 26, 951-955.

Simpson, S. J., and Simpson, C. L. (1990). "The mechanisms of nutritional compensation by phytophagous insects," in Insect-Plant Interactions, ed E. A. Bernays (Boca Raton, FL: CRC Press), 111-160. 
Skewgar, E., Boersma, P. D., Harris, G., and Caille, G. (2007). Sustainability: anchovy fishery threat to Patagonian Ecosystem. Science 315, 45. doi: 10.1126/ science. 1135767

Stephens, D. W., and Krebs, J. R. (1986). Foraging Theory. Princeton, NJ: Princeton University Press.

Tank, S. E., Schindler, D. W., and Arts, M. T. (2003). Direct and indirect effects of UV radiation on benthic communities: epilithic food quality and invertebrate growth in four montane lakes. Oikos 103, 651-667. doi: 10.1034/j.16000706.2003.12198.x

Teichberg, M., Fox, S. E., Olsen, I. S., Valiela, I., Martinetto, P., Iribarne, O., et al. (2010). Eutrophication and macroalgal blooms in temperate and tropical coastal waters: nutrient enrichment experiments with Ulva spp. Glob. Chang. Biol. 16, 2624-2637. doi: 10.1111/j.1365-2486.2009.02108.x

Tyler, R. M., and Targett, T. E. (2007). Juvenile weakfish Cynoscion regalis distribution in relation to diel-cycling dissolved oxygen in an estuarine tributary. Mar. Ecol. Prog. Ser. 333, 257-269. doi: 10.3354/meps333257

Villafañe, V. E., Sundbäck, K., Figueroa, F. L., and Helbling, E. W. (2003). "Photosynthesis in the aquatic environment as affected by UVR," in UV Effects in Aquatic Organisms and Ecosystems, eds E. W. Helbling and H. E. Zagarese (Cambridge, UK: Royal Society of Chemistry), 357-397.

Vinebrooke, R. D., and Leavitt, P. R. (1999). Differential responses of littoral communities to ultraviolet radiation in an alpine lake. Ecology 80, 223-237. doi: 10.1890/0012-9658(1999)080[0223:DROLCT]2.0.CO;2

Wetsteyn, L. P. M. J., and Kromkamp, J. C. (1994). Turbidity, nutrients and phytoplankton primary production in the Oosterschelde (The Netherlands) before, during and after a large-scale coastal engineering project (1980-1990). Hydrobiologia 282/283, 61-78. doi: 10.1007/BF00024622

Wilson, J. G. (2008). “Adaptations to life in estuaries," in Encyclopedia of Life Support Systems (EOLSS), ed P. Safran (Oxford: Eolss Publishers), 166-180.
Winder, M., and Sommer, U. (2012). Phytoplankton response to a changing climate. Hydrobiologia 698, 5-16. doi: 10.1007/s10750-012-1149-2

Yorio, P., and Quintana, F. (2008). “Aves marinas del Mar Argentino," in Estado de Conservación del Mar Patagónico y Áreas de Influencia (Puerto Madryn: Fundación Patagonia Natural), 202-226.

Zar, J. H. (1999). Biostatistical Analysis. Englewood Cliffs, NJ: Prentice Hall.

Conflict of Interest Statement: The Associate Editor, Peter Richter, declares that despite having collaborated with the author Donat-P. Häder, the review process was handled objectively. The authors declare that the research was conducted in the absence of any commercial or financial relationships that could be construed as a potential conflict of interest.

Received: 07 June 2014; paper pending published: 20 June 2014; accepted: 14 July 2014; published online: 07 August 2014.

Citation: Valiñas MS, Bermejo P, Galbán L, Laborda L, Häder D-P, Villafañe VE and Helbling EW (2014) Combined impact of ultraviolet radiation and increased nutrients supply: a test of the potential anthropogenic impacts on the benthic amphipod Amphitoe valida from Patagonian waters (Argentina). Front. Environ. Sci. 2:32. doi: 10.3389/fenvs.2014.00032

This article was submitted to Environmental Toxicology, a section of the journal Frontiers in Environmental Science.

Copyright (C) 2014 Valiñas, Bermejo, Galbán, Laborda, Häder, Villafañe and Helbling. This is an open-access article distributed under the terms of the Creative Commons Attribution License (CC BY). The use, distribution or reproduction in other forums is permitted, provided the original author(s) or licensor are credited and that the original publication in this journal is cited, in accordance with accepted academic practice. No use, distribution or reproduction is permitted which does not comply with these terms. 